\title{
Application of Big Data Analytics in Customization of E-mass Service: Main Possibilities and Obstacles
}

\begin{abstract}
The paper is based on a scientific literature analysis and, by examining scientific insights, it focuses on the assumption that Big Data Analytics (BDA) is an alternative used in modern organizations in decision making at e-mass service customization. An overall orientation to BDA application in management processes is presented as a useful construct not only for improving the decision-making procedure but also as a relevant source for strategic planning, process and cost optimization activities as well as for changes in supply chain and risk management. The data was obtained through the scientific literature analysis and systematized theoretical insights of the BDA influence in both possibility and obstacle dimensions to e-mass service customization.
\end{abstract}

Keywords: e-mass customization, Big Data, Big Data Analytics (BDA), service management.

Straipsnyje, remiantis mokslinès literatūros analize, teoriškai apibrěžiamos ir paaiškinamos mokslinès ¡̨žvalgos apie didžiųjų duomenų ir didžiụjų duomenų analitikos semantinę reikšmę bei taikymą šiuolaikiniu organizacijų vadyboje. Pagrindinis autoriaus dèmesys skiriamas teorinių prielaidų apžvalgai ir apibendrinimui apie didžiųjų duomenų analitikos taikymo galimybes ir problemas e. masiniame paslaugų individualizavime. Apskritai straipsnyje didžiųjų duomenų analitikos fenomenas yra pristatomas ir siejamas ne su siauru, instrumentinio-technologinio pobūdžio panaudojimu, o traktuojamas kaip vienas iš šaltinių ir aplinkybių, lemiančių procesinius, sisteminius ir struktūrinius pokyčius organizacijų planavimo, sprendimų priemimo, procesų ir kaštų optimizavimo bei rizikų valdymo veiklose.

Raktiniai žodžiai: elektroninis masinis individualizavimas, didieji duomenys, didžiųjų duomenų analitika, paslaugų individualizavimas.

\section{Introduction}

In recent few years, terms and models of Big Data and Big Data Analytics (BDA) have shown a tremendously increased attention and application in Management Science as well as in practices of business organization management. The root cause of that is that the last two decades focused on traditional, technology-driven attitude and quantitative data indicators as well as E. F. Codd model whereas a new model has switched onto a qualitative data indicators, combined analysis methods and data-driven business network and ecosystems (Ogrean, 2018; OrengaRoglá and Chalmeta, 2019). Accordingly, the result of this ongoing transition is widespread capabilities of BDA quantitative and qualitative application 
and, therefore, an extended semantical meaning. At this point, the concept shifted from a narrow understanding of technological-instrumental tool to a status of strategic resource, influential condition and functionality to support business transformation processes. From a perspective of process management, a rapid transition and modification of $3 \mathrm{~V}$ data management model to $4 \mathrm{~V}, 5 \mathrm{~V}$ (2012), 7V (2014) and final 10V (2018) models should be outlined (Grover and Kar, 2017; Asllani and Long, 2018; Ogrean, 2018; Sun, 2018). It is important to note that the final $10 \mathrm{~V}$ model is an outcome summary of insights by Sun (2018), formulated following principles of four preceding $3 \mathrm{~V}, 4 \mathrm{~V}, 5 \mathrm{~V}$, and $7 \mathrm{~V}$ models, composed by the researcher in this paper. The concept of e-mass customization also marks key points of practical service management orientation of the last decade as well as advantages of BDA regarding customers and processes towards organizational management activities. It is emphasized that mentioned management concepts, Big Data and its analytical methods can be aligned and applied together in practice to ensure an appropriate ratio of qualitative and quantitative costs and customer experience indicators, an overall environmental impact and value co-creation processes (George et al. 2014; Baesens et al. 2016; Hofman, 2017). In this context, the research question of this paper is formulated: What impact an application of Big Data and BDA can make on e-mass service customization? Consequently, the aim of this paper is to reveal a semantical transition of data management terms analysed in this paper as well as to identify main possibilities and obstacles which might occur within the inclusion of BDA results in e-mass service management. Therefore, the objectives of this paper are defined as follows:

1. To explore and clarify the influence and links of semantical and historical contexts for Big Data, BDA and mass service customization;

2. To reveal the complexity and dynamics of Big Data and BDA content;

3. To define possible advantages and obstacles of Big Data and BDA inclusion in modern organizations.

To achieve the objectives of this paper, the methods of literature overview, analysis, and information synthesis are applied with an employment of a qualitative research paradigm. The scientific literature overview and analysis are mostly adopted in a fulfilment of the first objective, in the initial chapter, however, the second chapter appears to be a significant source for information synthesis as well. Moreover, information synthesis and overview assist in clarifying general aspects which reveal the research aim to appear disparate and interdisciplinary. Furthermore, the selected research period of recent 5 years supports the relevance of results brought by applying this method. Moreover, the method of information synthesis is applied in both research chapters as well as focused to second and third objectives. Finally, the outcome of this method is identified in the evaluation of Big Data and BDA terms in 4 dimensions, in the framework of Big Data and BDA relation and content as well as in definition of positive and negative synergy points of Big Data and BDA phenomenon with an e-mass customization domain. 


\section{Literature overview of studies on Big Data: theoretical insights from semantical and retrospective points of view}

The term of Big Data is complex, dynamic and multidimensional not even from semantical but also from retrospective and logical points of view. Starting evaluation from a historical point, a number of interpretations and debates are identified and in general represents 2 major positions:

a) The term originated in the middle of 1990s and evolved from organization practices and combinations towards fields of computer science, statistics and econometrics. The main person at this is point is John Mashey from Silicon Graphics Inc. (SGI) and his presentation in 1998 where this term was mentioned first time in public (Diebold, 2012).

b) The term originated from the scientific research in the beginning of 1990s. It is claimed that the Big Data term first time in academic references was used in 1993 by Ulrich Schwardmann (Parallelization of a multigrid solver on the KSR1). Other significant input and research at this stage was made by Sholom Weiss and Nitin Indurkhya (1998) (Predictive Data Mining: A Practical Guide) (in the computer science field) and Francis X. Diebold (2000) (Big Data Dynamic Factor Models for Macroeconomic Measurement and Forecasting) (in the statistics and econometrics field) (Ogrean, 2018).

In addition, there is also a third position where the origination of Big Data as well as BDA is related to Douglas Laney
(2001) (3-D data management: controlling data volume, velocity and variety. Application delivery strategies by META Group Inc.) who suggested the conceptual $3 \mathrm{~V}$ model of data management and characteristics. At this point, there are arguments that this model also enriches the semantical meaning and marks a shift from phenomena based interpretation to concept or discipline based interpretation (Diebold, 2012; Ogrean, 2018; Politaite, Sabaitytė, 2018). The overall development of the analysed term, both in historical and semantical meanings, can be illustrated in a simplified way in Figure 1.

Taking into consideration semantical meanings of Big Data and BDA, mismatches and a diversification of positions are noticed. First, an evaluation in narrow and broad senses should be separate and discussed in a more detailed sense. Broadly, these terms cover a wide spectre and cover a constantly changing list of phenomena, including scientific, technological, and cultural dimensions (Boyd and Crawford, 2012; Politaitè and Sabaityte, 2018). Narrowly, 4 main dimensions of evaluation and their focus areas can be defined in Table 1 bellow.

Several different approaches to Big Data and BDA, which are presented in table above, have clear backgrounds as well as possible negative consequences. It is agreed both in practice and academic research field that these terms have a status of strategic resources which has a direct relation and influence on an ongoing technological development of society as well as new directions of academic studies in the past decade. Moreover, s strong relation to the digital business transformation should be emphasized as well. When analysing possible negative consequences, 


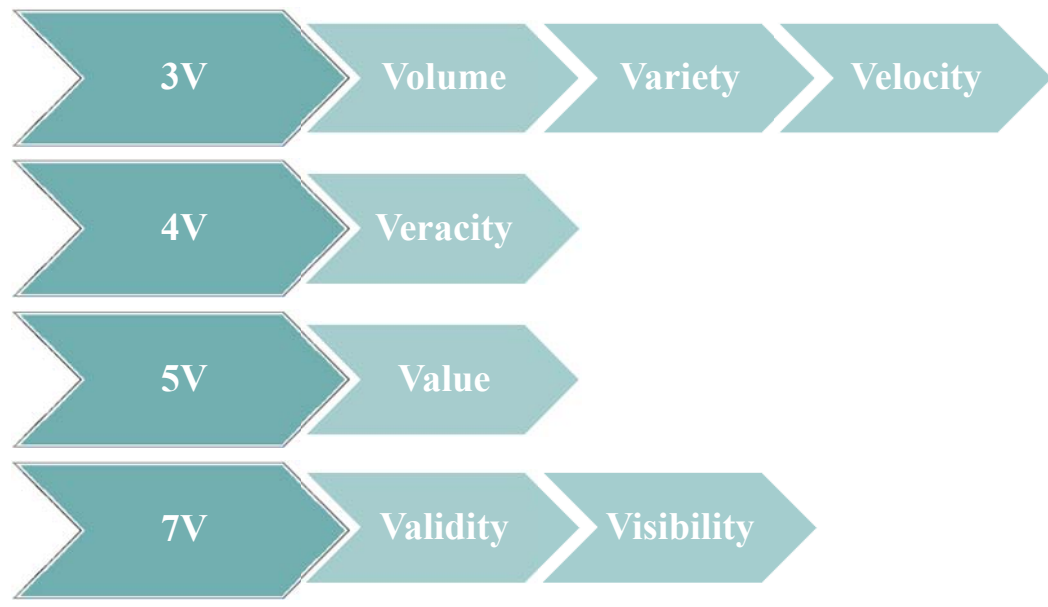

Fig. 1. Development of 3V model to $7 \mathrm{~V}$ model

Source: composed by the author based on resources: A. Asllani and D. M. Long (2018); J. E. Grable and A. C. Lyons (2018); C. Ogrean, (2018); S. Politaitè and J. Sabaitytè (2018).

Table 1. Evaluation of Big Data and BDA terms in a narrow sense

\begin{tabular}{|c|c|c|}
\hline Dimension & Definition & Focus area \\
\hline Technological & $\begin{array}{c}\text { Combination of structured (in-house } \\
\text { database or data warehouse) and } \\
\text { unstructured (external data sources) } \\
\text { data and data sets. }\end{array}$ & $\begin{array}{c}\text { Big data platforms and sources; } \\
\text { heterogenic and dynamic data } \\
\text { environment. }\end{array}$ \\
\hline Process / Procedural & $\begin{array}{c}\text { Data analysis process and results } \\
\text { application based on use and } \\
\text { combination of BDA related } \\
\text { technologies but not traditional, } \\
\text { statistical computer analysis and } \\
\text { tools. }\end{array}$ & $\begin{array}{c}\text { Application of BDA technology; } \\
\text { functions of data collection, } \\
\text { management and analyses. }\end{array}$ \\
\hline Systematic & $\begin{array}{c}\text { Alignment among BDA technologies, } \\
\text { Knowledge Management, process } \\
\text { and systems used in organization. }\end{array}$ & $\begin{array}{c}\text { Combination of BDA technologies, } \\
\text { Data Infrastructure, systems and } \\
\text { process capabilities; systematic } \\
\text { innovation capability. }\end{array}$ \\
\hline Management & $\begin{array}{c}\text { Inclusion of Big Data and BDA to } \\
\text { organization management model } \\
\text { and usage of results for competitive } \\
\text { advantage. }\end{array}$ & $\begin{array}{c}\text { Management organization; Resource } \\
\text { Based View (RBV); competitive } \\
\text { advantage in long term run. }\end{array}$ \\
\hline
\end{tabular}

Source: composed by the author based on M. A. Lambrou (2016), A. Asllani and D. M. Long (2018), J. E. Grable and A. C. Lyons (2018). 
it is important to mention that in practice these 2 terms are often used in a merged way, as having the same semantical meaning, as well as understood in a narrow approach where the orientation refers only onto technological or process/procedural dimensions (Asllani and Long, 2018; Sun, 2018).

In summary, it is important to note that Big Data and BDA do not have any strict content of definition or framework for implication in practice but currently a number of characteristics and non-linear interrelationships are identified, well defined and can be easily unified in the framework (Figure 2).

Three levels of the framework above reveal essential similarities and differences as well as content and relation points of
Big Data and BDA terms. First, Big Data serves as a fundamental level for all related activities and phenomena and is described from the perspective of $4 \mathrm{~V}$ model characteristics. At this framework, BDA is interpreted as a technological consequence of Big Data and has a strong relation with infrastructure elements that are needed to manage and transform numerous quantities of raw data to relevant insights for thee intelligence use. In this context, the semantical meaning of BDA term should be presented too. Accordingly, BDA stands for a combination of modern computer technologies, algorithms, systems, related management work practices and competencies for a large-scale of Big Data exploration, analysis and storage for short and long

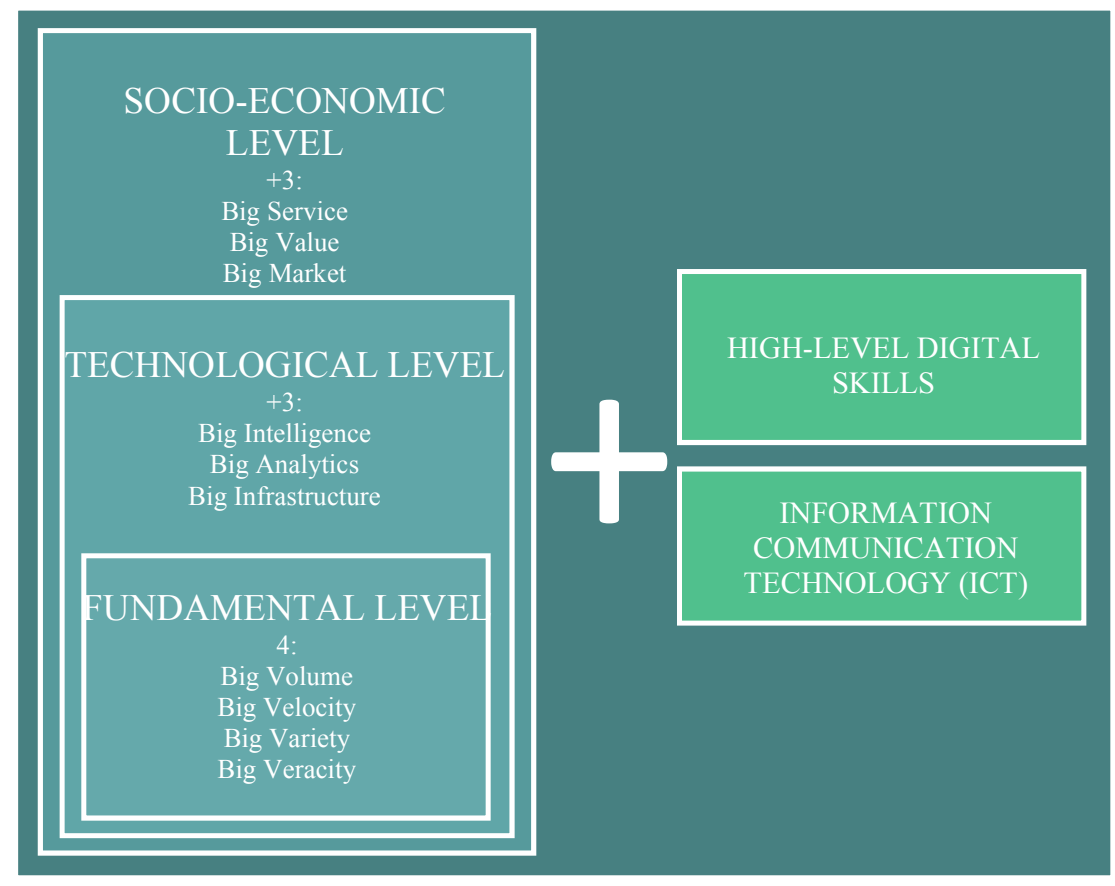

Fig. 2. Framework of Big Data and BDA relation and content 
term goals in organizations. Specifically, the main goal of BDA is to discover new insights about used products or services, business models as well as to identify existing and forecast new market trends for gaining a competitive edge (Chen et al., 2015; Politaitè and Sabaitytè, 2018; Sun, 2018). It should be noted that a widely discussed value of Big Data and its analytics are found at socio-economic level where they are applied to different markets and sectors but only after a foundation of related service and organizations networks. Moreover, a demand of adjusted usage of Information and Communication Technology (ICT) and human resources with specific, high level digital operations and personal skills are required to ensure a smooth organizational transformation and value creation (Chen et al., 2015; Sun, 2018).

\section{Application of Big Data Analytics in e-mass service customization}

Mass Customization as a multidisciplinary customer centric concept is well known in academic research of supply-value chain and operational process improvement topics as well as applied widely in business organizations practice for last 3 decades (Skačkauskienè and Davidavičius, 2015). Moreover, in recent years, an orientation of this concept to a user-driven product or service customization, indicators of customer satisfaction and involvement have been strongly affected by recent trends of digitalization, process automation and BDA. Therefore, this adaptation of technological innovations and attitude to a customer role have extended boundaries of the concept and formulated the e-mass customization. E-mass customization is defined as an acquisition of competitive advantage through combinations of technological and management methods as well as delivering a large scale and individualized product/service to a mass consumer in a cost-effective way. The main difference from a traditional Mass Customization is that at least 1 of 3 main dimensions (customer, product/service or process) in this version of concept is digital and online. Moreover, customer engagement is ensured not only in design level but also in production and operation level activities (Kaplan and Haenlein, 2006; Skačkauskienė and Davidavičius, 2015). Furthermore, at this point a valuable inclusion of both existing internal (for instance, customer profile, searching history) and dynamic external (for example, customer flow) environment data and their analyses can be made by using BDA. These modern technologies of information evaluation and network tools enable not only creating a more flexible and customized manufacturing/service model but also improving a quality of customer knowledge base and building an integrated knowledge management model in an organization too (Kaplan and Haenlein, 2006; Park and Yoo, 2016; Grover and Kar, 2017).

The influence of Big Data and BDA phenomena to the overall management area in a scientific discourse is recognized too. The period of 2012-2013 can be treated as a breaking period as then a relevant content of academic studies increased more than 3 times, lining from 17 to 73 (Ogrean, 2018). Reasons of this new trend, when a transition from Big Data to BDA occurred in the last decade, are both semantical and content type as well 
as containing a broad specter of external factors: data has become a background and essential part of business model transformation as organizations now have expanded their capabilities of IT and its infrastructure. Thus, an adoption of automation and digitalization ideas has rocketed as service optimization via bots and other automation solutions has become inevitable. In past few years, an integrated value (for customers and organizations) creation and measurement of its influence, complementary organizations networks and ecosystems have become a dominant topic here (Prince, 2017; Ogrean, 2018; Politaitè and Sabaitytè, 2018).

Switching to the synergy points of Big Data and BDA phenomena with an e-mass customization domain, the main similarities can be found in different perspectives:

- Historical conditions: objects of both analyses were strongly affected by the breaking point of the Information and Network technologies evolution in last decade of XX century. This period marks not only changes in quantitative paradigms and indicators but also in the qualitative assessment paradigm. Elaborating more into details, a shift from a narrow technologicalinstrumental type and a process level to a broader attitude on organizational management perspective can be identified in this context (Park and Yoo, 2016; Asllani and Long, 2018, Ogrean, 2018).

- Derivative phenomena: objects of both analyses were affected by a common historical context, environmental dynamism as well as made a theoretical and practical impact themselves to the development of organizations' strategy, operations and resource management and input to numerous customer-centric concepts as Mass Personalization, Value Co-creation, Learning Organization, Knowledge Management, Open Innovation, etc.) (Chen et al., 2015; Lambrou, 2016; Risdiyono et al., 2016; Asllani and Long, 2018).

Furthermore, Big Data and BDA are evaluated as an additional opportunity that should be used by modern organizations in decision making of e-mass service customization as well as evaluating an existing customization index, solving issues of alignment between self-congruity and functional congruity. On the other hand, there are concerns that a business or government organization have not yet reached the target maturity level so they could integrate data into their process or service improvements. In addition, organizations and businesses might have already reached their targets and integrated data into their activities but they do not continue making incremental process or service improvements. At this point, distinctions among sectors should be defined but currently, the business sector takes leadership in changes of customization concept (Welborn, 2009; Chen et al., 2015; Lambrou, 2016). In summary, the main 4 categories of application possibilities and obstacles are presented in Table 2.

The main benefits of adapting BDA to e-mass customization might be identified in categories of process management and service content improvement. Positive influence in process management here is described from different perspectives: a) Ensured deeper alignment and synergy level within organization boundaries (units in structure, process, and systems) as well as with external environment; b) Additional 
Table 2. Application of BDA to e-mass customization

\begin{tabular}{|c|c|c|}
\hline Category of influence & Main possibilities & + \\
\hline Technological & - & + \\
\hline Legal & - & + \\
\hline Content & + & + \\
\hline Process & + & Main obstacles \\
\hline
\end{tabular}

Source: composed by the author based on M. Aldanondo et al. (2003), C. Welborn (2009), D. Q. Chen et al. (2015), H. Moon and H-H. Lee (2015), B. Baesens et al. (2016), D. Krishna (2016), M. Park and J. Yoo (2016), P. Grover and A. K. Kar (2017), A. Asllani and D. M. Long (2018).

assist in supply and value chain management, strategic planning and change management; c) Better outcome of analyses and configuration activities: additional data source for customer requirement analysis and constraint-based modelling, improved evaluation of process flexibility and the effect of intangibility in online mass customized platforms and service (Aldanondo et al., 2003; Welborn; 2009; Moon and Lee, 2015; Park and Yoo, 2016; Grover and Kar, 2017; Gillespie et al., 2018). Furthermore, BDA is described as making a solid input to the content of e-mass customization decisions. In this instance, main points of influence improve identification of weak parts of the supply chain, user interface touchpoint or analyses of customer behaviour

Table 3. Possible obstacles of BDA inclusion to service management and customization

\begin{tabular}{|c|l|}
\hline Type & \multicolumn{1}{c|}{ Content } \\
\hline Technological & $\begin{array}{l}\text { Variety of Big Data sources, their content dynamic and complexity bring new, next level of } \\
\text { qualitative and quantitative technological requirements for organizations' systems and pro- } \\
\text { cesses as well as requires high-level digital skills and knowledge level of human operators. }\end{array}$ \\
\hline Legal & $\begin{array}{l}\text { Legal requirements of the General Data Protection Regulation Act are a regulation } \\
\text { in data protection and privacy for European Union based organizations, which oper- } \\
\text { ate customer data. It focuses not only on the alignment of legal indicators but also on } \\
\text { requirements of new roles, responsibilities and actions on a daily basis of data man- } \\
\text { agement, primary and support type of customer service activities. In accordance with } \\
\text { structural and process changes both in customization process management and BDA ac- } \\
\text { tivities should be implemented and the constant quality of data security should be ensured. }\end{array}$ \\
\hline Process & $\begin{array}{l}\text { Mentioned characteristics of Big Data, integrity of BDA results and ongoing digital transfor- } \\
\text { mation in customer service management are related not only to technological and legal chang- } \\
\text { es in organizations. It is also a non-linear way that has influence to a wide spectre of areas in } \\
\text { organization: a) In learning systems and processes which should be transformed and focus } \\
\text { more on retrain employees, creation of a new model of sourcing employees and talent acquisi- } \\
\text { tion; b) In internal and external communication processes; c) Updated quality control and risk } \\
\text { management activities. Furthermore, general alignment and consensus between internal and } \\
\text { external third parties, organization strategy and customer-centric approach are required too. }\end{array}$ \\
\hline
\end{tabular}

Source: composed by the author based on A. M. Kaplan and M. Haelein (2006), D. Q. Chen et al. (2015), H. Moon and H-H. Lee (2015), B. Baesens et al. (2016), D. Krishna (2016), M. Park and J. Yoo (2016), P. Grover and A. K. Kar (2017), A. Asllani and D. M. Long (2018). 
patterns and market trends (Krishna, 2016; Hofman, 2017; Asllani and Long, 2018). Moreover, BDA in modern organization practice has been adjusted innovatively and used in broader aspects, also affects a list of processes, systems and structural changes in a non-linear way. Otherwise, the application of BDA both in e-mass customization and overall organizational management faces various obstacles (Table 3).

Summarizing all the above-defined points of obstacles in BDA application, it should be noticed that these concerns are strongly related to a critical position. Big Data and BDA are defined more like a temporary trend and a group of rhetorical labels than a separate scientific management concept or a specific category in technical or computational practices (Boyd and Crawford, 2012; Prince, 2017). Moreover, general obstacles in practices are identified: modern organizations in terms of the BDA usage in customization processes are still at a pre-stage or at a transition stage. In other words, organizations try to identify and define data sources and their content, try finding out how to get relevant insights from BDA, modelling possible application areas in customer value creation and integration to e-mass customization. At the same time organizations evaluate the need for a technological base and management competence update, prepare for upcoming structural and process changes (Chen et al., 2015; Lambrou, 2016).

\section{Conclusions}

The semantical meaning, a scope of content and practical application possibilities of Big Data and BDA significantly have developed during the last two decades.
Otherwise, a rapidly increasing orientation to customer-centric concepts and a user-driven value co-creation not only require modern data management and analysing tools but also a full transition to digitalization and mass customized online service models. A concept and practical model of e-mass customization illustrates this recent trend of hybrid (combined) operations management as well as reveals new obstacles, especially in organizational learning, legal and technological domains. In practice, adoption of Big Data and BDA is supposed to give support for daily networking with customers, operating a huge amount of information and solving manageability concerns for all involved entities. It is believed that BDA inclusion can guarantee a more successful result in transformation to or renewal of the e-mass customization model both in short and long term runs. But at this point, an open question for further comprehensive and enlarged scope of scientific literature research hangs on - how and in which scope this combination of technology and management domains is bridging the academicpractice gap (in the field of customer data collection, advanced analytics and application to customized mass service management model)? Moreover, while from the theoretical perspective possible benefits and synergy points of analysis objects seem to be numerous and easily reached, in practice, however, organizations are facing a list of negative consequences or obstacles for adoption. A decision to adopt BDA techniques to the e-mass service and overall organizational management is often based on unbalanced assumptions of upcoming effect or improper and narrow interpretations of 
requirements for set up. In this case, additional questions arise: how to properly evaluate and prioritize (in time and cost- effective investment criteria) the need of BDA for the existing service management practice and customization models?

\section{References}

1. Aldanondoa, M., Hadj-Hamou, K., Moynard, G., Lamothe, J. (2003). Mass Customization and Configuration: Requirement Analysis and Constraint Based Modeling Propositions // Integrated Computer-Aided Engineering. Vol. 10, pp. 177-189.

2. Asllani, A., Long, D. M. (2018). Management Science and Big Data: A Text Mining Meta Analysis Study // Journal of Management Policy and Practice. Vol. 19, No. 2, pp. 103-115. doi: https://doi.org/10.33423/jmpp.v19i2.1280

3. Baesens, B., Bapna, R., Marsden, J. M., Vanthienen, J., Leon Zhao, J. (2016). Transformational Issues of Big Data and Analytics in Networked Business // MIS Quarterly. Vol. 40, No. 4, pp. 807-818. doi: 10.25300/MISQ/2016/40:4.03

4. Boyd, D., Crawford, K. (2012). Critical Questions for Big Data: Provocations for a Cultural, Technological, and Scholarly Phenomenon, Information // Communication \& Society. Vol. 15, No. 5, pp. 662-679.

5. Chen, D. Q., Preston, D. S., Swink, M. (2015). How the Use of Big Data Analytics Affects Value Creation in Supply Chain Management // Journal of Management Information Systems, Vol. 32, No. 4, pp. 4-14. doi: 10.1080/07421222.2015.1138364

6. Diebold, F. X. (2012). A Personal Perspective on the Origin(s) and Development of "Big Data": The Phenomenon, the Term, and the Discipline, Second Version // PIER Working Paper. Vol. 13, No. 003, pp. 1-4. doi: 10.2139/ssrn.2202843

7. George, G., Haas, M. R., Pentland, A. (2014). Big Data and Management // Academy of Management Journal. Vol. 57, No. 2, pp. 321326. doi: 10.5465/amj.2014.4002

8. Gillespie, B., Otto, C., Young, C. (2018). Bridging the Academic-Practice Gap Through Big Data Research // International Journal of Market Research. Vol. 60, No. 1, pp. 11-13. doi: $10.1177 / 1470785317744670$
9. Grable, J. E., Lyons, A. C. (2018). An Introduction to Big Data // Journal of Financial Service Professionals. Vol. 72, No. 5, pp. 17-20.

10. Grover, P., Kar, A. K. (2017). Big Data Analytics: A Review on Theoretical Contributions and Tools Used in Literature // Global Journal of Flexible Systems Management. Vol. 18, No. 3, pp. 203-208. doi: 10.1007/s40171-017-0159-3

11. Hofman, E. (2017). Big Data and Supply Chain Decisions: The Impact of Volume, Variety and Velocity Properties on the Bullwhip Effect // International Journal of Production Research. Vol. 55, No. 17, pp. 5108-5126. doi: 10.1080/00207543.2015.1061222

12. Kaplan, A. M., Haenlein, M. (2006). Toward a Parsimonious Definition of Traditional and Electronic Mass Customization // The Journal of Product Innovation Management. Vol. 23, pp. 168-182.

13. Krishna, D. (2016). Big Data in Risk Management // Journal of Risk Management in Financial Institutions. Vol. 9, No. 1, pp. 46-51.

14. Lambrou, M. A. (2016). Innovation Capability, Knowledge Management and Big Data Technology: A Maritime Business Case // International Journal of Advanced Corporate Learning. Vol. 9, No. 2, pp. 40-43. doi: 10.3991/ ijac.v9i2.6010

15. McKay, E., Mohamad, M. B. (2018). Big Data Management Skills: Accurate Measurement // Research \& Practice in Technology Enhanced Learning. Vol. 13, No. 5, pp. 1-3. doi: 10.1186/ s41039-018-0071-2

16. Moon, H., Lee, H-H. (2015). The Effect of Intangibility on the Perceived Risk of Online Mass Customization: Utilitarian and Hedonic Perspectives // Social Behavior and Personality. Vol. 43, No. 3, pp. 457-466. doi: 10.2224/ sbp.2015.43.3.457

17. Ogrean, C. (2018). Relevance of Big Data for Business and Management. Exploratory Insights (Part I) // Studies in Business and 
Economics. Vol. 13, No. 2, pp. 153-161. doi: 10.2478/sbe-2018-0027

18. Orenga-Roglá, S., Chalmeta, R. (2019). Framework for Implementing a Big Data Ecosystem in Organizations.//Communications of the ACM. Vol. 62, No. 1, pp. 58-65. doi: $10.1145 / 3210752$

19. Park, M., Yoo, J. (2016). E-mass Customization: Effects of Self-congruity and Functional Congruity on Consumer Responses // Social Behavior and Personality. Vol. 44, No. 8, pp. 1379-1394. doi: https://doi.org/10.1111/ jpr.12084

20. Politaité, S., Sabaitytė, J. (2018). Didžiujuu duomenų naudojimas klientui pažinti // Science - Future of Lithuania. Vol. 10, pp. 1-10. doi: https://doi.org/10.3846/mla.2018.932

21. Prince, C. (2017). Big Data and Privacy: Why Public Organizations Adopt Big Data // The Canadian Journal of Information and Library Science. Vol. 41, No. 4, pp. 233-240.
22. Risdiyono, R., Widodo, I. D., Mahtarami, A. (2016). Mass Customization and Personalization Prospects in Developing Country: Indonesian Context // IOP Conference Series: Materials Science and Engineering. Vol. 105, pp. 1-5. doi: 10.1088/1757-899X/105/1/012046

23. Skačkauskienè, I., Davidavičius, S. (2015). Masinio individualizavimo koncepto ypatumai // Business: Theory and Practice. Vol. 16, No. 2, pp. 132-139.

24. Sun, Z. (2018). 10 Bigs: Big Data and Its Ten Big Characteristics // BAIS No. 17010, pp. 1-7. doi: 10.13140/RG.2.2.31449.62566

25. Welborn, C. (2009). Customization Index: Evaluating the Flexibility of Operations in a Mass Customization Environment // ICFAI Journal of Operations Management, Vol. 8, pp. 6-11.

The paper submitted: May 25, 2019

Prepared for publication: December 10, 2019

\section{Gedas BARANAUSKAS DIDŽIŲJŲ DUOMENỤ ANALITIKOS TAIKYMAS E. MASINIAME PASLAUGŲ INDIVIDUALIZAVIME: GALIMYBĖS IR KLIŪTYS}

\section{S a n tra u k a}

Straipsnyje, remiantis pastarujų 5 metų mokslinès literatūros analize ir informacijos sinteze, teoriškai apibrěžiamos ir paaiškinamos mokslinès įžvalgos apie didžiụjų duomenų ir didžiųjų duomenų analitikos semantinę reikšmę bei taikymą šiuolaikinių organizacijų vadyboje. Temos aktualumą lemia ne tik didelis demesys moksliniuose šaltiniuose ir praktinis žinomumas, bet ir bendros pastarojo dešimtmečio organizacijų vadybos tendencijos - technologinių sprendimų ir naujų duomenų šaltinių taikymas, personalizuoto požiūrio ị klientą bei poreikio tam įsitvirtinimas, organizacijų tinklų ir ekosistemų išplitimas. Visa tai praplète didžiųjų duomenų analitikos ir e. masinio individualizavimo reikšmes, susiejant juos su verslo modelių transformacijų ir konkurencinio pranašumo igijimo reiškiniais. Tačiau greta stebimos ir klaidingos semantinès interpretacijos formuojamas dèl iki galo neapibrezžto ir ¿̇vairialypio (plačiąa ir siaurąa prasme) straipsnio temos terminų turinio traktavimo. Lygiagrečiai identifikuojama ir praktinio taikymo problematika, sietina tik su siauru, instrumentinio-technologinio pobūdžio didžiưjų duomenų ir jų analitikos panaudojimu. Apibendrinant mokslines įžvalgas sukurta 10 didžiųjų duomenų reiškinio charakteristikų, sąveikaujančių tarpusavyje netiesioginiais ryšiais 3 struktūrinių lygių sistemoje bei reikalavimų naudotojui ir infrastruktūrai ryšių schema. Taip pat straipsnyje yra teoriškai apibendrinamos 3 pagrindinès didžiųjų duomenų analitikos taikymo paslaugų valdyme ir individualizavime problematikos sritys bei identifikuojamos 4 galimo teigiamo ir neigiamo poveikio kategorijos e. masiniame paslaugų individualizavime. Ateityje temos moksliniai tyrimai turètų būti orientuoti ị didesnès apimties ir detalesnes analizes, vertinant tiek vadybos ir technologinių sprendimų kombinavimą ir jo poveikị praktikams bei teoretikams, tiek specifinių didžiųjų duomenų analitikos priemonių ir sprendimų poreikị ir vietą masinių paslaugų individualizavime. 